\title{
Long term conservation of embryonic axes of genipap accessions
}

Conservação a longo prazo de eixos embrionários de acessos de jenipapeiro

\author{
C. M. Nascimento ${ }^{1}$; L. A. R. Oliveira ${ }^{2}$; A. V. C. Silva ${ }^{2}$; E. M. Castro 3 ; A. S. \\ Lédo $^{2 *}$ \\ ${ }^{1}$ Universidade Federal de Sergipe, 49100-000, São Cristóvão-Sergipe, Brazil \\ ${ }^{2}$ Embrapa Tabuleiros Costeiros, 49025-040, Aracaju-Sergipe, Brazil \\ ${ }^{3}$ Universidade Federal de Lavras, 37200-000, Lavras-Minas Gerais, Brazil \\ *ana.ledo@embrapa.br
}

(Recebido em 21 de agosto de 2019; aceito em 10 de fevereiro de 2020)

\begin{abstract}
The ex situ conservation of seeds in cryobanks demands previous studies of dehydration procedures for the adjustment of the adequate moisture that makes long-term conservation possible. The objective of this work was to evaluate the effect of dehydration time on the regenerative capacity of embryonic axes of two genipap accessions (Umbaúba and Núcleo Bandeirante). Seeds were submitted to desiccation in policarbonate box containing silica gel for $0,12,16$ and $20 \mathrm{~h}$ at room temperature and after each period, seed moisture content was determined. Seeds were inoculated in germination medium and samples were inserted into cryotubes and immersed in liquid nitrogen $\left(-196^{\circ} \mathrm{C}\right)$. Desiccation in silica gel was efficient in reducing the moisture content in both accessions. Umbaúba accession presented $100 \%$ germination at all desiccation treatments before cryopreservation and Núcleo Bandeirante was more sensitive to desiccation with $10 \%$ germination in $20 \mathrm{~h}$. Umbaúba accession showed a reduction of growth variables with increased desiccation time. The treatments tested did not affect the growth variables of Núcleo Bandeirante accession. The desiccation, although changes observed in the ultra-structures of embryonic axis, did not influence the regeneration percentage of cryopreserved accessions.

Keywords: Genipa americana L., tissue culture, cryopreservation.
\end{abstract}

A conservação ex situ de sementes em bancos criogênicos exige estudos prévios de procedimentos de desidratação para o ajuste da umidade adequada que possibilita a conservação em longo prazo. O objetivo deste trabalho foi avaliar o efeito do tempo de desidratação sobre a capacidade regenerativa de eixos embrionários de dois acessos de jenipapo, Umbaúba e Núcleo Bandeirante. As sementes foram submetidas à dessecação em caixas de policarbonato contendo sílica gel por $0,12,16$ e $20 \mathrm{~h}$ em temperatura ambiente e, após cada período, o teor de umidade da semente foi determinado. As sementes foram inoculadas no meio de germinação e amostras para cada período foram inseridas em criotubos e imersas em nitrogênio líquido ($\left.196^{\circ} \mathrm{C}\right)$. A dessecação em sílica gel foi eficiente na redução do teor de umidade (\% mc) de ambos os acessos. O acesso Umbaúba apresentou $100 \%$ de germinação em todos os tempos de dessecação antes da criopreservação e o Núcleo Bandeirante foi mais sensível à dessecação com 10\% de germinação em 20 h. O acesso Umbaúba apresentou uma redução das variáveis de crescimento com o aumento do tempo de dessecação. Os tempos testados não afetaram as variáveis de crescimento do acesso Núcleo Bandeirante. O tempo de dessecação, apesar das alterações nas ultraestruturas do eixo embrionário, não influenciou a porcentagem de regeneração dos acessos criopreservados.

Palavras-chave: Genipa americana L., cultura de tecidos, criopreservação.

\section{INTRODUCTION}

Genipap (Genipa americana L.), a native species belonging to Rubiaceae family, is found in northern South America and Central America. Genipap, as it is popularly known, has potential for socioeconomic use and is used for various purposes, among them for food and textile industrials, wood exploitation and medicines. For presenting resistance to soaked soils, it arouses great interest for the recovery of degraded areas, permanent preservation areas, among others [7, 23].

The species has fruits widely appreciated in the Northeastern region of Brazil, and despite the great demand in the region, it is still exploited in an extractive way [30]. The conservation of its 
genetic resources is mainly based on field collections, due to the physiology of its seeds, which present intermediate behavior in storage, not tolerating desiccation at extremely low levels $[5,18]$. In order to ensure the ecological and economic sustainability of the species, several research institutions have conserved its genetic diversity in the field [29].

The advancement of biotechnological techniques presents the cryopreservation as a strategy complementary to conservation. Cryopreservation consists of preserving the biological material at ultra low temperatures using liquid nitrogen at $-196^{\circ} \mathrm{C}$, or at its vapor phase at $-150^{\circ} \mathrm{C}$ for long periods [3]. Cryopreservation becomes a viable procedure for the preservation of biological material for long periods of time, requiring reduced space and little maintenance $[2,26]$.

There are different cryopreservation methods, especially dehydration, encapsulation dehydration, droplet-vitrification and vitrification [11]. These techniques have been successfully used for different explants in Citrus sp. [13]; Coffea arabica L. [9], Hancornia speciosa Gomes [20, 25, 26], Genipa americana L. [23, 24], Pistacia vera L. [1] and Ananas comosus L.) Merr. [31]. Different explants can be cryopreserved as embryonic axes, apical meristems and calluses [25].

The intracellular water content is a limiting factor for the survival of the cryopreserved explant, thus dehydration is essential, which can be physical through evaporation promoted by the exposure of the material to silica gel or laminar flow cabinet or by the use of cryoprotectants that cause osmotic dehydration of the material $[14,22]$. The reduction of water from explants to extremely low levels to avoid the formation of ice crystals is the most critical step in obtaining a successful cryopreservation protocol [12].

Many damages can be caused to frozen samples with inadequate water content such as: mechanical disorganization of plant structures, mechanical damage resulting from cell volume reduction and cell membrane injury [24]. Tolerance to dehydration varies from species to species and among tissues of the same plant, and appropriate humidity must be reached to ensure adequate survival of the material [22]. Besides that, desiccation tolerance is directly related to changes in cellular components, to the activation of antioxidant enzyme systems, to oligosaccharides and to heat-resistant proteins $[3,8,28]$.

The ex situ conservation of seeds in cryobanks demands previous studies of dehydration procedures for the adjustment of the adequate moisture that makes long-term conservation possible. Several classical methods of evaluating seed viability have been applied; however, the in vitro culture of embryos or embryonic axes also allows the evaluation of the physiological integrity of cryopreservation [24].

The present work had as objective to evaluate the effect of different dehydration times in silica gel on the regenerative capacity of cryopreserved embryonic axes of different genipap accessions.

\section{MATERIAL AND METHODS}

\subsection{Plant Material}

Genipap (Genipa americana L.) seeds from mature fruits, collected in 2017 from plants of natural populations of Núcleo Bandeirante, Federal District (15 51'55.72"S; 47 $57^{\prime} 34.59^{\prime \prime} \mathrm{W}$ ) and Umbaúba, Sergipe accessions ( $\left.11^{\circ} 1^{\prime} 56.1^{\prime \prime S} ; 37^{\circ} 41^{\prime} 32.8^{\prime \prime W}\right)$, were used as source of explants. Seeds were manually extracted and washed with detergent until the pulp was completely removed and immersed in ethyl alcohol $\left(\mathrm{C}_{2} \mathrm{H}_{5} \mathrm{OH}\right)$ at $70 \%$ for 3 min and in sodium hypochlorite $(\mathrm{NaOCl})$ solution at 2 to $2.5 \%$ for $15 \mathrm{~min}$ and then rinsed three times and dried for $24 \mathrm{~h}$ at room temperature $\left(24^{\circ} \mathrm{C} \pm 2^{\circ} \mathrm{C}\right)$.

\subsection{Effect of desiccation time on the moisture content and viability of genipap accessions before cryopreservation}

To obtain the germination percentage (control 1), seeds were inoculated in MS culture medium [17] with $30 \mathrm{~g} / \mathrm{L}$ sucrose and $3.5 \mathrm{~g} / \mathrm{L}$ Phytagel® (germination medium).

For studies desiccation effects on the germination of embryonic axes, seeds were submitted to desiccation in magenta boxes containing $50 \mathrm{~g}$ of silica gel $\left(\mathrm{SiO}_{2}\right)$ for $0,12,16$ and $20 \mathrm{~h}$ at room 
temperature. Seed moisture (five samples of 10 seeds per genotype) was determined for each desiccation time. After that, seeds were inoculated in germination medium, as described above, and two samples of 10 seeds for each treatment were immediately inserted into cryotubes and immersed in liquid nitrogen $\left(-196^{\circ} \mathrm{C}\right)$.

To determine the initial moisture content of seeds and after desiccation, three replicates of five seeds were weighed to obtain the wet weight $\left(\mathrm{W}_{\mathrm{w}}\right)$ and transferred to laboratory oven for $72 \mathrm{~h}$ at $105^{\circ} \mathrm{C} \pm 3^{\circ} \mathrm{C}$ to obtain the dry weight $\left(\mathrm{W}_{\mathrm{d}}\right)$. The moisture content, on wet basis $\left(\% \mathrm{mc}_{\mathrm{wb}}\right)$ was determined by the following equation: $\% \mathrm{mc}_{\mathrm{wb}}=\left[\left(\mathrm{W}_{\mathrm{w}}-\mathrm{W}_{\mathrm{d}}\right) / \mathrm{W}_{\mathrm{w}}\right] \times 100$.

To evaluate the germination percentage after cryopreservation, cryotubes were thawed in water bath at $40^{\circ} \mathrm{C} \pm 2^{\circ} \mathrm{C}$ for $3 \mathrm{~min}$ and seeds were immersed in sterile water for $24 \mathrm{~h}$, according to Santos \& Salomão (2016) [24]. After this period, the embryonic axes were excised and inoculated in MS germination medium.

Variables percentage germination, shoot and root length and number of leaves were measured after each germination test at 60 days. The design was completely randomized in a $2 \times 4$ factorial scheme (two genotypes and four desiccation times), with five replicates, with plot being represented by 50 seeds.

\subsection{Effect of desiccation time on the regeneration and growth of genipap accessions after cryopreservation}

To obtain the germination percentage (control 1), fresh seeds were inoculated in previously described MS culture medium. For studies on the effect of desiccation on the germination of embryonic axes, seeds were submitted to desiccation in magenta boxes containing $50 \mathrm{~g}$ of silica gel for $0,12,16$ and $20 \mathrm{~h}$ at room temperature. Seed moisture (five samples of 10 seeds per genotype) was determined for each desiccation period. After that, seeds were inoculated in the germination medium (control 2) and two samples of 10 seeds for each desiccation time were immediately placed into cryotubes and immersed in liquid nitrogen $\left(-196^{\circ} \mathrm{C}\right)$. To evaluate the germination percentage, cryotubes were thawed in water bath at $40^{\circ} \mathrm{C} \pm 2^{\circ} \mathrm{C}$ for 3 min and seeds were immersed in sterile water for $24 \mathrm{~h}$, after which the embryonic axes were excised and immediately inoculated in MS culture medium with $30 \mathrm{~g} / \mathrm{L}$ sucrose and $3.5 \mathrm{~g} / \mathrm{L}$ Phytagel ${ }^{\circledR}$.

The regeneration percentage, shoot and root lengths and number of leaves were evaluated after each germination test at 60 days. The design was completely randomized in a $2 \times 4$ factorial scheme (two genotypes and four desiccation times), with five replicates, with plot being represented by 50 seeds.

\subsection{Histological analyses}

Analyses were carried out in the laboratories of Plant Anatomy and Laboratory of Electron Microscopy and Ultrastructure Analysis of the Federal University of Lavras. Embryonic axes were excised from seeds and fixed in formaldehyde FAA (formalin, acetic acid and ethyl alcohol) [6]. Samples were then submitted to $70 \%, 80 \%, 90 \%$ and $100 \%$ alcohol gradient at $2 \mathrm{~h}$ intervals for dehydration. Subsequently, samples were infiltrated by $100 \%$ ethanol + liquid resin (1:1) by $2 \mathrm{~h}$. Activated resin $=$ infiltration solution (resin + activator powder, as indicated by the manufacturer) by $24 \mathrm{~h}$ in refrigerator. Subsequently, the inclusion solution was prepared by adding the hardener to the infiltration resin or activated resin (following the proportions indicated by the manufacturer).

Plant fragments were infiltrated into $6 \mathrm{~mm}$ x $8 \mathrm{~mm}$ Leica ${ }^{\circledR}$ histomolds (plastic forms suitable for inclusion). At the time of inclusion, fragments were adequately positioned and polymerized in a laboratory oven at $37^{\circ} \mathrm{C}$. Blocks were kept with low humidity, stored in containers with good sealing and content silica gel. After material inclusion, microtomy was performed using semiautomatic rotating microtome that was standardized at cut thickness ranging from 5 to $8 \mu \mathrm{m}$. Then, they were spread over the slide containing a small amount of water. After drying at room temperature, slides were stained using the Toluidine Blue dye prepared in acetate buffer ( $\mathrm{pH}$ 4.7). After 3 min, slides were washed in acetic water until excess of dye was removed. After drying, slides were fixed with Etterlan ${ }^{\circledR}$, and later observed under a Nikon Eclipse E100 microscope coupled to Infinity 1 camera, where they were photomicrographed. 


\subsection{Statistical Analyses}

All data were subjected to one-way ANOVA and means compared by the Tukey's Test and differences at $P \leq 0.05$ were considered to be significant. For studies of qualitative effects and regression equations for quantitative effects were estimated. Statistical analyses were performed with the SAS-9.4 program [27].

\section{RESULTS}

\subsection{Effect of desiccation time on the moisture content, germination and growth of genipap accessions before cryopreservation}

There was significant effect of interaction between accession and desiccation time on seed moisture content $(\mathrm{mc})$ and germination percentage $P<0.05$ (Table 1 ).

Table 1. Analysis of variance of seed moisture content (MC) and germination percentage (GE) of genipap accession seeds submitted on different desiccation times.

\begin{tabular}{lccc}
\hline Source & DF & MS MC & MS GE \\
\hline Accession (A) & 1 & $92.1592^{* *}$ & $27562.5000^{* *}$ \\
Desiccation Time (T) & 3 & $195.5522^{* *}$ & $2229.1667 * *$ \\
$\mathbf{A} * \mathbf{T}$ & 3 & $57.5130^{* *}$ & $2229.1667 * *$ \\
error & 16 & 1.6965 & 437.5000 \\
\hline VC & & 9.64 & 24.37 \\
\hline
\end{tabular}

** Significantly different at $p=0.01$ by F's Test. DF-Degrees of freedom; $M S$ - means of Sum of squares; VC-Variation Coefficient.

As show in Figure 1A, the Núcleo Bandeirante accession presented linear behaviour. At time $\mathrm{T} 0$, the mc was $15.48 \%$, with the exposure to silica gel at different periods, the mc was reduced with minimum of $9.86 \%$ in $20 \mathrm{~h}$. For the Umbaúba accession, the seed mc presented quadratic behaviour. At T0 treatment, the mc was $28.46 \%$, with reduction of the water content, the minimum mc reached was $9.0 \%$ in $20 \mathrm{~h}$ of exposure to silica gel. Umbaúba accession obtained $100 \%$ germination at all desiccation time tested. However, Núcleo Bandeirante accession after T0 treatment presented a drastic reduction of germination showed linear behaviour (Figure 1B).
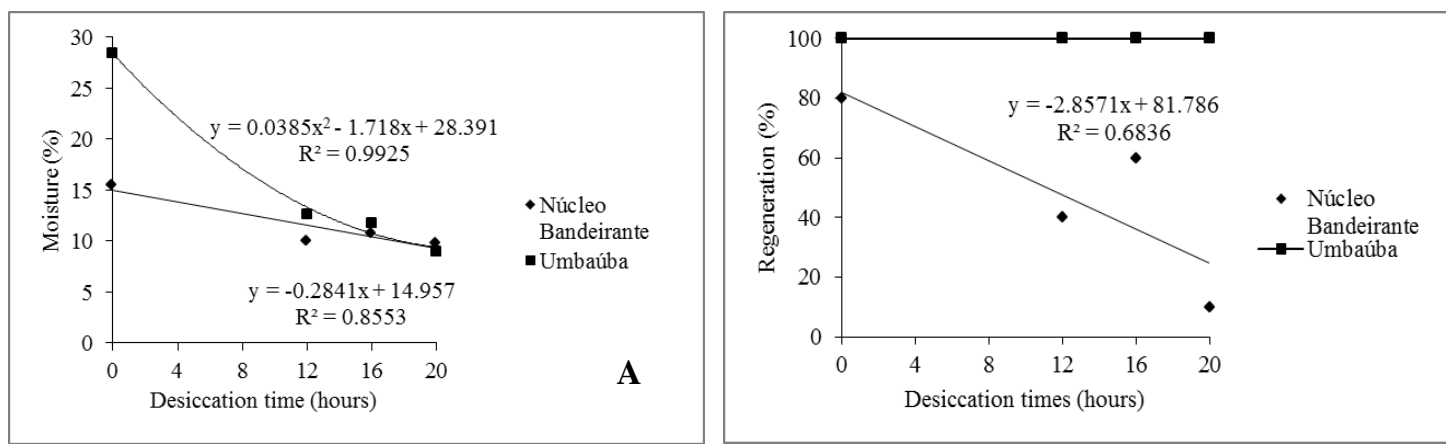

B

Figure 1. A- Effect of desiccation time on moisture content and regeneration of genipap accessions; $B$ Effect of desiccation time of seeds on the regeneration of genipap accessions.

Regarding the growth variables for Umbaúba accession, there was a significant effect of desiccation time for shoot length and number of leaves $(P<0.05)$ and no effect on root length at 60 days of in vitro culture (Table 2). Shoot length and number of leaves presented linear behaviour (Figures 2A-B).

For shoot length, time T0 (control) was higher with mean of $4.28 \mathrm{~cm}$, with linear reduction at the different desiccation times, reaching minimum value of $1.34 \mathrm{~cm}$ in $20 \mathrm{~h}$. For number of leaves, the same behaviour was observed with higher T0, with mean of 2.0 leaves. Considering the root length, exposure to silica gel negatively influenced the speed at which radicle protrusion occurred, 
root length exhibits linear regression. At time T0, it presented mean of $5.64 \mathrm{~cm}$, reaching minimum value of $2.92 \mathrm{~cm}$ in $20 \mathrm{~h}$ (Figure 2C).

Table 2. Analysis of variance of shoot length (SL), root length (RL) and number of leaves (NL) of Umbauba accession plantlets submitted on different desiccation times before cryopreservation.

\begin{tabular}{lllll}
\hline Source & DF & MS SL & MS RL & MS NL \\
\hline Desiccation Time (T) & 3 & $7.2751^{*}$ & $6.2613^{\text {ns }}$ & $3.7833^{* *}$ \\
error & 16 & 1.8425 & 3.3967 & 0.5250 \\
\hline VC & & 13.14 & 24.06 & 8.56 \\
\hline
\end{tabular}

** Significantly different at $p=0.01$ by $F$ 's Test, * Significantly different at $p=0.05$ by $F$ 's Test; $n s$-not significantly; DF- Degrees of freedom; MS- Means of sum of squares; VC-Variation Coefficient

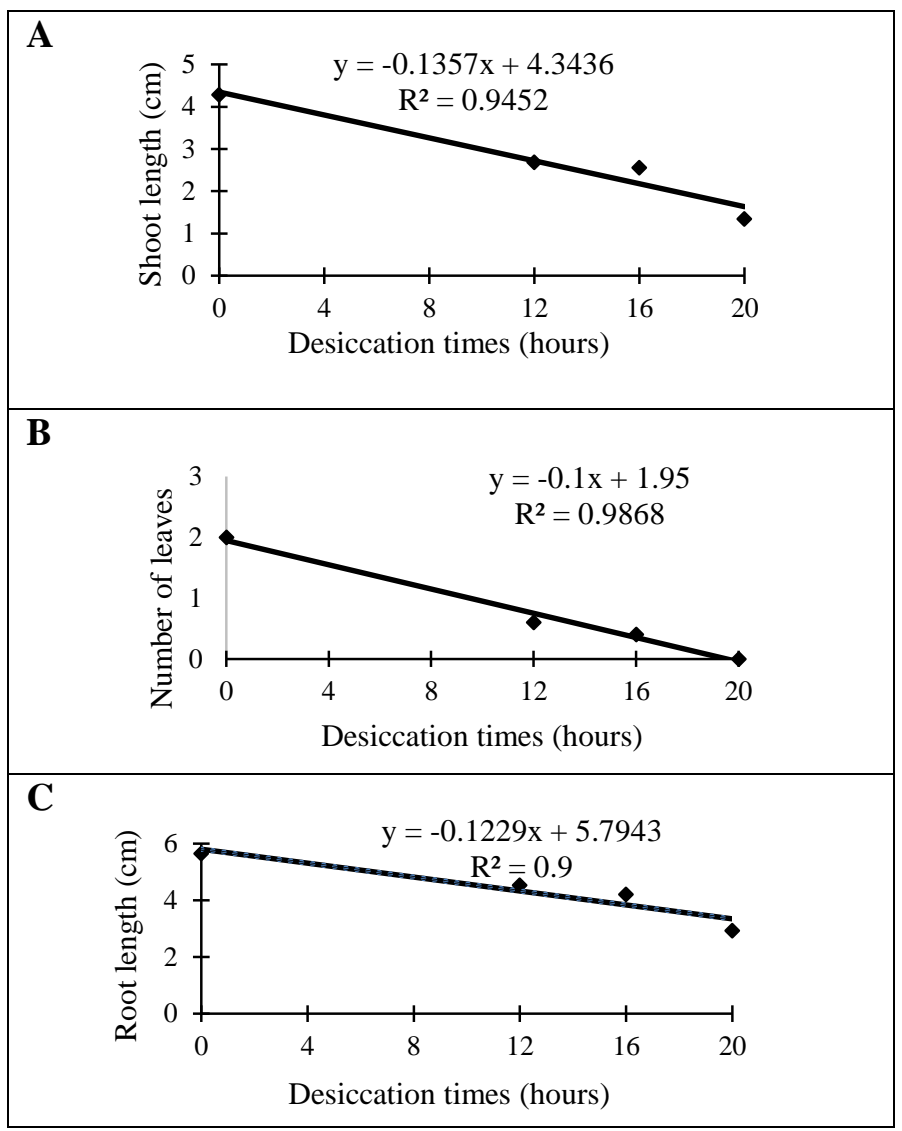

Figure 2. Effect of desiccation time on silica gel of Umbaúba accession plantlets at 60 days of in vitro before cryopreservation: A-shoot length; $B$ - number of leaves and $C$-root length.

As show in Table 3, for Núcleo Bandeirante accession there was no significant effect of desiccation time on shoot length, root length and number of leaves at 60 days of in vitro culture $(P$ $>0.05)$. Due to drastic reduction of germination percentage at time T20 $(20 \mathrm{~h})$ of desiccation the growth variables were not evaluated.

Table 3. Effect of desiccation time on the shoot length $(S L)$, root length $(R L)$ and number of leaves $(N L)$ of Núcleo Bandeirante accession plantlets at 60 days of in vitro culture.

\begin{tabular}{clcc}
\hline Desiccation times (hour) & SL $(\mathbf{c m})$ & RL $(\mathbf{c m})$ & NL \\
$\mathbf{0}$ & $4.36 \mathrm{a}$ & $4.00 \mathrm{a}$ & $2.00 \mathrm{a}$ \\
$\mathbf{1 2}$ & $4.25 \mathrm{a}$ & $3.62 \mathrm{a}$ & $1.75 \mathrm{a}$ \\
$\mathbf{1 6}$ & $3.80 \mathrm{a}$ & $3.34 \mathrm{a}$ & $1.40 \mathrm{a}$ \\
\hline $\mathbf{C V}(\boldsymbol{\%})$ & 8.05 & 8.03 & 10.14 \\
\hline
\end{tabular}

Means in a column followed by a same letter were not significantly different at $p=0.05$ by Tukey's Test. 


\subsection{Effect of desiccation time on the regeneration and growth of genipap accessions after cryopreservation}

There was no significant effect of desiccation time on the regeneration percentage of cryopreserved embryonic axes at 60 days of in vitro culture $(P>0.05)$ for both accessions, according Table 4. The results for Umbaúba accession showed high regeneration of embryogenic axes percentage from $90 \%$ to $100 \%$ and for Núcleo Bandeirante accession from $80 \%$ to $100 \%$.

Table 4. Effect of desiccation time on the regeneration percentage of embryonic axes of genipap accessions at 60 days of in vitro culture after cryopreservation.

\begin{tabular}{ccc}
\hline Desiccation times (hour) & Umbaúba & Núcleo Bandeirante \\
\hline $\mathbf{0}$ & $90 \mathrm{a}$ & $100 \mathrm{a}$ \\
$\mathbf{1 2}$ & $95 \mathrm{a}$ & $85 \mathrm{a}$ \\
$\mathbf{1 6}$ & $100 \mathrm{a}$ & $90 \mathrm{a}$ \\
$\mathbf{2 0}$ & $95 \mathrm{a}$ & $80 \mathrm{a}$ \\
\hline
\end{tabular}

$\frac{\text { CV (\%) } 9.11}{\text { Means in a column followed by a same letter were not significantly different at } p=0.05 \text { by Tukey's Test. }}$

Regarding in vitro growth after cryopreservation (Table 5), there was a significant effect of desiccation time for shoot and root lengths and number of leaves of seedlings regenerated from embryonic axes $(P<0.05)$.

Table 5. Analysis of variance of shoot length (SL), root length (RL) and number of leaves (NL) of Umbauba accession plantlets submitted on different desiccation times after cryopreservation.

\begin{tabular}{lllll}
\hline Source & DF & MS SL & MS RL & MS NL \\
\hline Accession (A) & 1 & $37.3456^{* *}$ & $48.1803^{* *}$ & $34.2250^{* *}$ \\
Desiccation Time (T) & 3 & $25.0810^{* *}$ & $17.8175^{* *}$ & $3.4250^{*}$ \\
$A^{* *}$ T & 3 & $0.3600^{\text {ns }}$ & $2.3283^{\text {ns }}$ & $4.7583^{\text {ns }}$ \\
error & 32 & 0.3823 & 1.0711 & 0.8125 \\
\hline VC & 21.79 & 24.94 & 23.81 \\
\hline ** Significantly different at $p=$ 0.01 by F's Test, * Significantly different at $p=0.05$ by F's Test; ns -not \\
significantly; DF- Degrees of freedom; MS- Means of sum of squares; VC- Variation Coefficient
\end{tabular}

With increasing desiccation time, there was a drastic linear reduction of shoot and root lengths (Figures 3A-3C). The number of leaves varied according to a quadratic equation, with reduction after 8 hours of desiccation (Figure 3B).
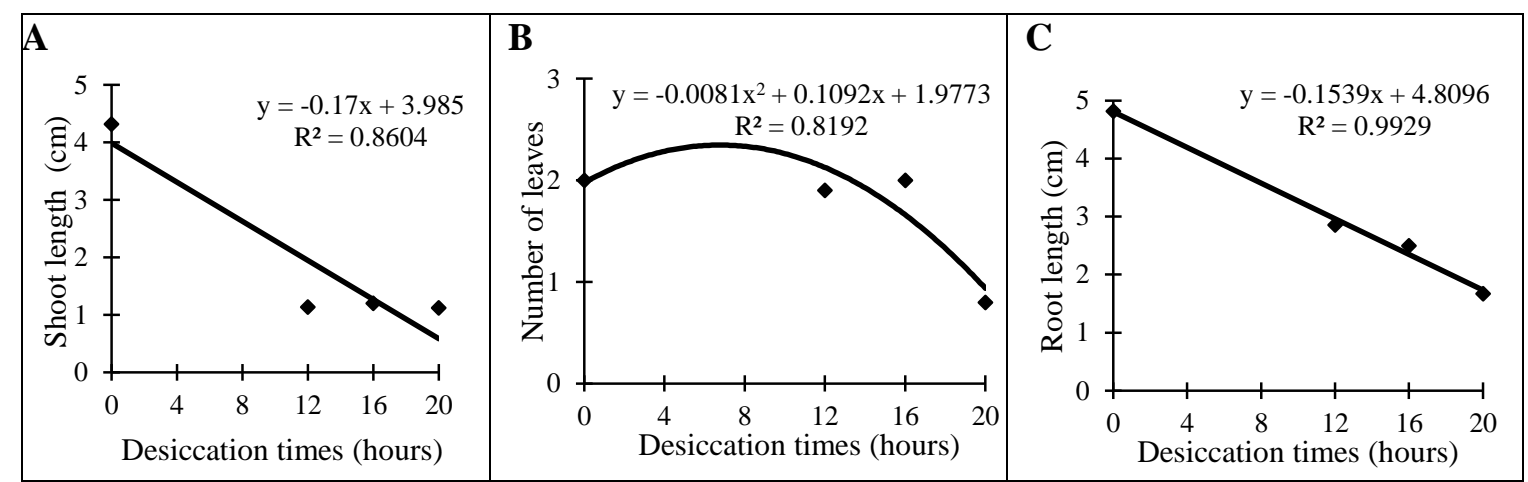

Figure 3. Effect of desiccation time on silica gel of Umbaúba accession plantlets at 60 days of in vitro after cryopreservation: A-shoot length; B-number of leaves and C-root length. 
There were significant effects of accessions for growth variables $(P<0.05)$. Umbaúba accession showed seedlings with higher root and shoot growth and number of leaves compared to Núcleo Bandeirante accession (Table 6).

Table 6. Effect of accession on shoot (SL), root length (RL) and number of leaves (NL) of genipap embryonic axes at 60 days of in vitro culture after cryopreservation.

\begin{tabular}{cccc}
\hline Accession & SL $(\mathbf{c m})$ & RL $(\mathbf{c m})$ & NL \\
\hline Umbaúba & $2.95 \mathrm{a}$ & $4.06 \mathrm{a}$ & $2.70 \mathrm{a}$ \\
Núcleo Bandeirante & $1.95 \mathrm{~b}$ & $1.87 \mathrm{~b}$ & $0.75 \mathrm{~b}$ \\
\hline CV $(\%)$ & 31.79 & 34.94 & 22.10
\end{tabular}

Means in a column followed by a same letter were not significantly different at $p=0.05$ by Tukey's Test.

As complementary analysis to the effect of desiccation and cryopreservation on the embryonic axes of Núcleo Bandeirante accession, the ultrastructural analysis was performed with Electron Microscopy and Optical Microscope. The external morphology of the non-cryopreserved zygotic embryo presented highly organized cells, with intact cell wall. The embryonic axis presents cylindrical shape and no apparent lesions and rounded cotyledons with no visual damage in its structure (Figure 4).

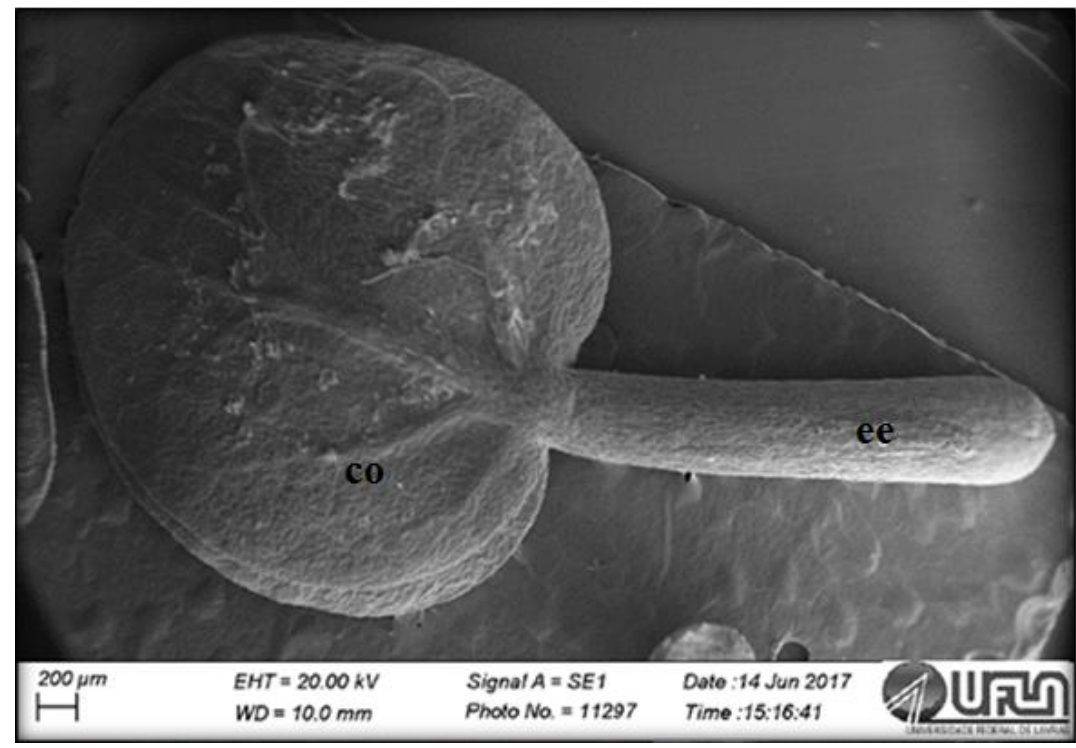

Figure 4. Zygotic embryonic structures of non-cryopreserved genipap. ryo: co-cotyledons; ee - embryonic axis in Scanning Electron Microscope.

Umbaúba accession seeds submitted to $12 \mathrm{~h}$ of desiccation with moisture from $10 \%$ to $13 \%$ presented wilted cell structure, observing a reduction of the cell wall and an increase of the intracellular space in seeds before immersion in LN (Figures 5A-B). Cells apparently with less intracellular space may have occurred due to tissue rehydration for a period of $24 \mathrm{~h}$ after thawing (Figures 5C-D). In spite of twice the desiccation time in relation to the previous treatment, the moisture content reached values close to $10 \%$, presenting the same damages shown above. 

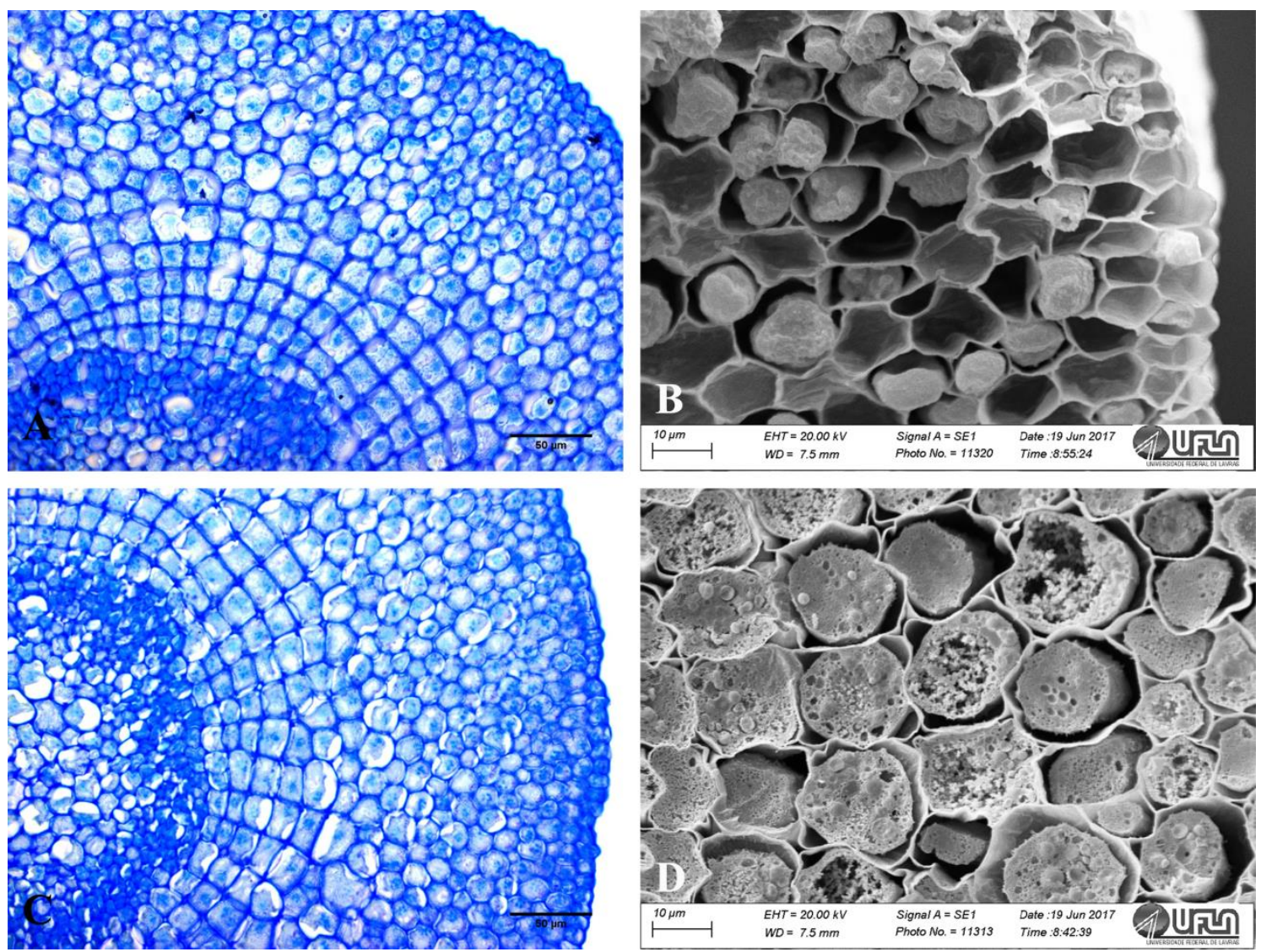

Figure 5: Cross-sectional section and scanning electromicrographs of the embryonic axis before and after cryopreservation (NL), with $12 \mathrm{~h}$ desiccation. A and B-embryonic axis cells before NL, $C$ and $D$ embryonic axis cells after $N L$.

\section{DISCUSSION}

The desiccation in silica gel reduced the mc to close values in both accessions. Similar results were observed by Santos \& Salomão (2016) [24] in genipap seeds from the Brazilian Cerrado. The initial mc of $43.89 \%$ decreased gradually, reaching minimum value of $6.79 \%$ in $36 \mathrm{~h}$ at different desiccation times in silica gel [24]. Silica gel provides fast drying in aseptic environment by adsorption of water in the pores of its surface [10]. The lower germination presented by Núcleo Bandeirante accession after the desiccation is probably due to the fact of its greater sensitivity to desiccation. According Spanó et al. (2011) [28] different protective mechanisms seem to act in combination but their relative importance changes as maturation progresses and in response to the drying method. There was formation of normal seedlings, with well-developed root and shoots and with no apparent damage at 60 days of in vitro culture in both accessions. Genipap has classification of intermediate seeds and cannot suffer drastic desiccation, tolerating approximately $10 \%$ of moisture content [5]. According to Bewley \& Black (1994) [4], the mechanisms of seed desiccation tolerance are acquired after histodifferentiation and are initiated by maternal tissues and not by environmental signals.

Recently harvested and germinated of genipap seeds present high germination percentage [18; 21], losing their viability as they are dried out. The loss of water associated with the speed with which it is removed may influence the viability of genipap seeds [16], which can impair processes related to recovery, and longer time is required for rehydration [19]. Carvalho \& Nascimento (2000) [5] studied the ability of genipap seeds submitted to different rapid drying procedures to tolerate desiccation, obtaining germination of $96 \%$ in fresh seeds $(39.8 \% \mathrm{mc})$ and values higher than $50 \%$ with moisture reduction after $24 \mathrm{~h}(10.3 \% \mathrm{mc})$. However, under continuous exposure up to $72 \mathrm{~h}$, seeds had mc of $6.2 \%$ and total loss of viability. Germination rates of $98 \% ; 91 \% ; 87 \% ; 68 \% ; 35 \%$ and $10 \%$ and $\mathrm{mc}$ of $46.9 \% ; 30.5 \% ; 20.8 \% ; 15.6 \% ; 10.2 \%$ and $5.4 \%$, respectively, were observed 
by Magistrali et al. (2013) [16] when studying the effect of the drying rate on desiccation tolerance and storage of genipap seeds.

Regarding the growth variables for Umbaúba accession, there was a significant effect of desiccation time for shoot length and number of leaves. There was no effect on root length at 60 days of in vitro culture.

For Núcleo Bandeirante accession, there was no significant effect of desiccation time on shoot length, root length and number of leaves at 60 days of in vitro culture. Due to the greater sensitivity of Núcleo Bandeirante accession to moisture reduction in comparison to Umbaúba accession, seedlings have lower growth development probably due to intrinsic mechanisms of tolerance to low moisture content.

The similar regeneration percentage presented by both accessions after cryopreservation. In relation to the accessions under study, there was no significant effect of the desiccation time on the regeneration percentage of cryopreserved embryonic axes at 60 days of in vitro culture.

There are few published studies on genipap in long-term conservation conditions. Recently results published by Santos \& Salomão (2016) [24] show after cryopreservation, embryonic axes of genipap reached high germination percentages, 93\%; 96\% and 93\%, in seeds with $13.26 \%$; $9.57 \%$ and $6.79 \% \mathrm{mc}$, respectively).

The growth responses after cryopreservation as to root length and number of leaves can be explained by greater rehydration capacity of Umbaúba accession cells after dehydration. According to Walters et al. (2001) [32], the normal functions of cells are altered when it is submitted to contents intermediate to those of total hydration. Several factors can cause damages and modifications in the physiological behavior of sensitive seeds during the desiccation process, among them maturation stage and temperature [14]. Benmahioul et al. (2015) [1] report the interaction between the water content of embryonic axes during freezing and seed viability.

Genetic-dependent responses after cryopreservation have been observed for other species. Differences in the regeneration capacity and development of embryonic axes of Gossipium hirsutum were reported by Lopes et al. (2013) [15]. Kaya \& Souza (2017) [12] evaluated three Saccharum officinarum genotypes using different cryopreservation techniques of apical meristems observed variation in regeneration and growth. High genotype-dependence was also reported by Souza et al. (2016) [31] among Ananas comosus accessions.

Ultrastructural changes of cells were observed with decrease of mc as reduction of storage cell volume and compaction in the internal reserve content and increase the intracellular space in the endosperm. Seeds with 5.4\% moisture presented uncharacterized cell morphology with loss of turgidity of cell walls. Similar results were obtained by Magistrali et al. (2013) [16] with scanning electromycrographs of genipap tissues rapidly dried up to $10.2 \%$ moisture.

\section{CONCLUSION}

The dehydration in silica gel can be applied to genipap accessions, considering that exposure to NL did not compromise the survival and regeneration of embryonic axes from Umbaúba and Núcleo Bandeirante seed accessions.

Desiccation in silica gel is efficient in reducing the moisture content (\% mc) of Umbaúba and Núcleo Bandeirante seed accessions.

Umbaúba accession presents $100 \%$ germination at all desiccation times on silica gel before cryopreservation and Núcleo Bandeirante is more sensitive to desiccation with $10 \%$ germination in $20 \mathrm{~h}$. Umbaúba accession presents a reduction of growth variables with increased desiccation time and the times tested do not affect the growth variables of Núcleo Bandeirante accession.

The desiccation time does not influence the regeneration percentage of embryonic axes of cryopreserved Umbaúba and Núcleo Bandeirante accessions.

The changes observed in the ultrastructures of the embryonic axis of genipap caused by desiccation do not affect the germination rate of cryopreserved seeds. 


\section{ACKNOWLEDGMENTS}

This study was financed by Empresa Brasileira de Pesquisa Agropecuária - Embrapa and the Coordenação de Aperfeiçoamento de Pessoal de Nível Superior - Brasil (CAPES - Finance Code 001).

\section{REFERENCES}

1. Benmahioul B, Daguin F, Kaïd-Harche M. Cryopreservation of Pistacia vera embryonic axes. J Forest Sci. 2015;61:182-187.

2. Benson EE. Cryopreservation Theory. In: Reed, B.M. Plant Cryopreservation- A Pratical Guide. Springer, New York, 2008, Pp. 15-32.

3. Berjak P, Bartels P, Benson EE, Harding K, Mycock DJ, Pammenter NW, Wesley-Smith J. Cryoconservation of South African plant genetic diversity. In Vitro Cell Dev - Pl. 2011;47(1):65- 81.

4. Bewley JD, Black M. Seeds: physiology of development and germination. Plenum Press, New York, 1994, $445 \mathrm{p}$.

5. Carvalho JEU, NascimentoWMO. Sensibilidade de sementes de jenipapeiro (Genipa americana L.) ao dessecamento e ao congelamento. Rev Bras Frutic. 2000;22:53-56.

6. Castro EM, Pereira FJ, Paiva R. Histologia vegetal: estrutura e função de órgãos vegetativos. Universidade Federal de Lavras, Lavras, 2009, 234 p.

7. Dantas ACVL, Costa MAP de C, Souza FVD, Santos ROS, Santos LSL. Jenipapo. In: Santos-Serejo JA dos, Dantas ACVL, Sampaio CV, Coelho Y da S. Fruticultura tropical: espécies regionais e exóticas. Brasília: Embrapa Informação Tecnológica, Brasília, 2009, Pp. 275-291.

8. Fernandes JS, Guimarães RM, Faria JMR, Pereira DS, Coelho SVB, Oliveira AS. Physiological and biochemical changes during desiccation tolerance loss in millet (Pennisetum glaucum L.) seeds. Acta Sci Agron. 2019;41:e36522. doi:10.4025/actasciagron.v41i1.36522

9. Figueiredo MA. Exploratory studies for cryopreservation of Coffea arabica L. seeds. J Seeds Sci. 2017;39:150-158. doi:10.1590/2317-1545v39n2171123

10. Fiore CL. Sílica gel para uso magistral. Rev Téc Farmac. 2013:14-16.

11. Kaviani B. Conservation of plant genetic resources by cryopreservation. Aust J Crop Sci. 2011;5:78800.

12. Kaya E, Souza FVD. Comparison of two PVS2-based procedures for 9 cryopreservation of commercial sugarcane (Saccharum spp.) germplasm and 10 confirmation of genetic stability after cryopreservation using ISSR markers. In Vitro Cell Dev - Pl. 2017;53:1-8. doi:10.1007/s11627-017-9837-2

13. Kaya E, Vidigal F, Gokdogan EY, Jenderek M. Cryopreservation of citrus seed via dehydration followed by immersion in liquid nitrogen. Turkish J Biol. 2017;41:242-248. doi:10.3906/biy-1603-92

14. Kermode AR, Finch-Savage BE. Desiccation sensitivity in orthodox and recalcitrant seeds in relation to development. In: Black M, Pritchard HW (Eds). Desiccation and survival in plants: drying without dying. CABI, London, 2002, Pp. 149-184.

15. Lopes KP, Almeida FAC, Carvalho JMFC, Bruno RLA. Criopreservação de eixos de embriões zigóticos de algodoeiro. Rev Bras Eng Agríc Amb. 2013;17:291-298.

16. Magistrali PR, José AC, Faria MR, Gasparin E. Physiological behavior of Genipa americana L. seeds regarding the capacity for desiccation and storage tolerance. J Seed Sci. 2013;35:495-500. doi:10.1590/S2317-15372013000400011

17. Murashige T, Skoog F. A revised medium for rapid growth and bioassays with tobacco tissue culture. Physiol Plant. 1962;15:437-497. doi:10.1111/j.1399-3054.1962.tb08052.x

18. Oliveira LM, Silva EO, Bruno RLA, Alves EU. Períodos e ambientes de secagem na qualidade de sementes de Genipa americana L. Semina: Ci Agr. 2011;2:495-502. doi:10.5433/16790359.2011v32n2p495

19. Oliver MJ, Bewley JD. Desiccation- tolerance of plant tissues: a mechanistic overview. Hortic Rev. 2010;18:271-213. doi:10.1002/9780470650608.ch3

20. Prudente DO, Paiva R, Nery FC, Paiva PDO, Reis MV, Silva LC. Criopreservação de gemas laterais de mangabeira: o papel da prolina. Rev Saúde Ci On Line. 2014;3:86-93.

21. Queiroz SE, Silva EA, Davide AC, José AC, Silva AT, Fraiz AC, Faria JM, Hilhorst HW. Mechanism and control of Genipa americana seed germination. Physiol Plant. 2012;144:263-276. doi:10.1111/j.1399-3054.2011.01554.x

22. Rocha MS. Caracterização morfofisiológica, criopreservação e resposta à salinidade de acessos de pinhão manso. Tese de Doutorado. Universidade Federal da Paraíba, Areia, $2010,156 \mathrm{p}$. 
23. Sá FP, Souza FVD, Muniz AVC da S, Ledo A da S. Encapsulamento, crioproteção e desidratação na capacidade regenerativa de ápices caulinares de Genipa americana. Ci Rural. 2015;45:1939-1945.

24. Santos IRI, Salomão NA. Viability assessment of Genipa americana L. (Rubiaceae) embryonic axes after cryopreservation using in vitro culture. Int J Agron. 2016:1-6. doi:10.1155/2016/7392710

25. Santos PAA, Paiva R, Silva LC, Silva DPC. Cryopreservation of the mangaba tree (Hancornia speciosa Gomes): a protocol for longterm storage. Acta Sci Agron. 2015;37:289-296. doi:10.4025/actasciagron.v37i3.19573

26. Sartor FR, Moraes AM, Almeida FAC. Técnicas para criopreservação de gemas de mangabeira. Rev Cienc Agrotec. 2012;3:31-39. doi:10.12971/2179-5959.v03n01a03

27. SAS Institute Inc. Statistical Analysis System, SAS 9.4 Help and Documentation, Cary, NC: SAS Institute Inc., 2013.

28. Spanó C, Bottega S, Grilli I, Lorenzi R. Responses to desiccation injury in developing wheat embryos from naturally- and artificially-dried grains. Plant Physiol Biochem. 2011;49(4):363-367. doi:10.1016/j.plaphy.2011.02.007

29. Silva Junior JF, Lédo AS, Silva AVC, Ramos SRR. Recursos genéticos de fruteiras nativas e adaptadas do nordeste: situação do germoplasma conservado ex situ na região. In: Congresso Brasileiro de Recursos Genéticos, 2., 2012, Bélem. Anais...Brasília, 2012, 1 CD-ROM.

30. Vieira RF, Agostini-Costa T da S, Silva DB da, Sano SM, Ferreira FR. Frutas nativas da região CentroOeste do Brasil. Brasília, Embrapa Recursos Genéticos e Biotecnologia, 2010, 320 p.

31. Souza FV, Kaya E, Vieira LJ, Souza EH, Amorim VBO, Skogerboe D, Matsumoto T, Alves AAC, Ledo CAS, Jenderek MM. Droplet-vitrification and morphohistological studies of cryopreserved shoot tips of cultivated and wild pineapple genotypes. Plant Cell Tiss Org. 2016;124:351-360. doi:10.1007/s11240-015-0899-8

32. Walters C, Pammenter NW, Berjak P, Crane J. Desiccation damage, accelerated ageing and respiration in desiccation tolerant and sensitive seeds. Seed Sci Res. 2001;2:135-148. doi:10.1079/SSR200168 